\title{
Measurement of postoperative cognitive dysfunction after cardiac surgery: a systematic review
}

\author{
James L. Rudolph ${ }^{\star}$, Kimberly A. Schreiber ${ }^{\dagger}$, Deborah J. Culley ${ }^{\ddagger}$, Regina E. McGlinchey§, \\ Gregory Crosby $\uparrow$, Sidney Levitsky $\|$, and Edward R. Marcantonio\# \\ *Geriatric Research Education and Clinical Center, VA Boston Healthcare System; Division of \\ Aging, Brigham and Women's Hospital; and Harvard Medical School, Boston, MA, USA \\ †Loyola University Chicago, Stritch School of Medicine, Maywood, IL, USA \\ $\neq$ Department of Anesthesiology, Brigham and Women's Hospital and Harvard Medical School, \\ Boston, MA, USA \\ $\S$ Geriatric Research Education and Clinical Center, VA Boston Healthcare System and Harvard \\ Medical School, Boston, MA, USA \\ IDepartment of Anesthesiology, Brigham and Women's Hospital and Harvard Medical School, \\ Boston, MA, USA \\ "Division of Cardiac Surgery, Beth Israel Deaconess Medical Center and Harvard Medical \\ School, Boston, MA, USA \\ \#Divisions of General Medicine and Primary Care and Gerontology, Beth Israel Deaconess \\ Medical Center and Harvard Medical School, Boston, MA, USA
}

\section{Abstract}

Background-Postoperative cognitive dysfunction (POCD) is a decline in cognitive function from preoperative levels, which has been frequently described after cardiac surgery. The purpose of this study was to examine the variability in measurement and definitions for POCD.

Methods-Electronic medical literature databases (EMBASE, MEDLINE, Psychinfo, and Cumulative Index of Nursing and Allied Health Literature) were searched for the intersection of the search terms: "thoracic surgery" and "cognition, dementia, and neuropsychological test". Abstracts were reviewed independently by 2 reviewers. English articles with more than 50 participants published since 1995 that performed preoperative and postoperative psychometric testing in patients undergoing cardiac surgery were reviewed in their entirety. Data relevant to the measurement and definition of POCD were abstracted and compared to the recommendations of a 1995 Consensus Statement on measurement of POCD.

Results-Sixty-two studies of POCD in patients undergoing cardiac surgery were identified. Of these studies, the recommended neuropsychological tests were done in less than half of the studies. Cognitive domains measured most frequently were attention $(\mathrm{n}=56 ; 93 \%)$ and memory $(\mathrm{n}=57 ; 95 \%)$; motor skills were measured less frequently $(\mathrm{n}=36 ; 60 \%)$. Four definitions of POCD emerged: percent decline $(n=15)$, standard deviation decline $(n=14)$, factor analysis $(n=13)$, and analysis of performance on individual tests $(n=12)$. Because of variability in its measurement, the prevalence of POCD varied by over 10-fold across studies.

Corresponding Author: James L. Rudolph VABHS GRECC, 150 South Huntington Ave, Boston, MA 02130 Phone:857-364-6812, Fax:857-364-4544, jrudolph@partners.org.

Conflict of Interest: The authors have no financial conflict of interest to declare 
Conclusion-There is marked variability in the measurement and definition of POCD. This heterogeneity may impede progress by reducing the ability to compare studies about the causes and treatment of POCD.

\section{Introduction}

Advances in surgical techniques, perfusion systems, and perioperative management have reduced the mortality associated with cardiac surgery ${ }^{1}$. However, postoperative cognitive dysfunction (POCD) remains a common outcome with potential to adversely impact quality of life ${ }^{2}, 3$. POCD is a decline in performance on neuropsychological tests relative to preoperative levels. To adequately capture cognitive performance in important domains, several neuropsychological tests are needed4. Because of the multiple tests used to assess a particular domain, the variability in scoring of these tests, and the high correlation between different tests; the methodology used to analyze the tests to arrive at a determination of impairment can have a large impact on the reported prevalence of POCD.5 One problem with variable criteria for POCD is that the results of studies may not be comparable.

Challenges with comparability of POCD measures have been recognized for a long time6. To address these challenges, the Statement of Consensus on Assessment of Neurobehavioral Outcomes after Cardiac Surgery (Consensus Statement), published in 1995, recommended the core battery, timing, and additional comorbid conditions for assessment of POCD. ${ }^{7}$ Since the publication of this statement, there have been many studies that have investigated POCD as a neuropsychological end-point after cardiac surgery, but whether they have followed the consensus statement is unknown. The purpose of this manuscript is to perform a comprehensive literature review to determine: a) if a standardized neuropsychological battery for POCD has emerged in accordance with Consensus Statement recommendations, b) if the comorbidities, assessment timing, and learning effect recommendations of the Consensus Statement are being utilized, and c) if standard analytic criteria for POCD have emerged.

\section{Materials and Methods}

\section{Search Methodology}

The study was conducted with approval of the IRB. We searched of the following databases: EMBASE, MEDLINE, Psychinfo, and Cumulative Index of Nursing and Allied Health Literature. Studies were reviewed between June 1995 and May 2009, limited to English language and human subjects. The cardiac surgery search term was created by the combination of the following medical subject headings (MeSH): "cardiac surgery, coronary artery bypass graft, heart surgery, OR thoracic surgery" and the keyword searches: "CABG, valve replacement, OR valve repair". The cognitive term included the MeSH terms "cognition, dementia, neuropsychology, OR neuropsychological tests" combined with the keywords "post operative cognitive dysfunction, dementia, cognitive impairment, OR neuropsychological tests." The abstracts identified from the intersection of the cardiac surgery and cognitive terms were independently reviewed by two reviewers and relevant studies were identified for full text review. The intersection was limited to the dates of interest, human studies, English language, and adults ( $\geq 18$ years). Criteria for full text review included: children were not the study population, patients underwent cardiac surgery, and cognitive function was measured. For abstracts with a disagreement among reviewers, the manuscript was reviewed to determine if the study met inclusion criteria. Additionally, the reference list of selected articles was reviewed for additional articles of interest. 


\section{Study Selection Criteria}

Manuscripts selected for inclusion were prospective studies of cardiac surgery patients that assessed both preoperative and postoperative cognitive function. Studies were excluded that used a cognitive screening test, such as the Mini Mental State Examination ${ }^{8}$, as the only measure of cognitive function. Studies of cardiac procedures such as angiography, angioplasty, or valvuloplasty were excluded. We excluded studies with $<50$ patients and intervention studies with $<25$ patients per arm, because these studies would lack the size to accurately define POCD. Studies that assessed POCD solely in the first three postoperative days were excluded, because the distinction of POCD from postoperative delirium would be clouded. ${ }^{9}$ Studies with multiple publications from the same cohort were reviewed, but were reported once.

\section{Measurement Variables}

From the selected studies, we abstracted study characteristics, patient demographics and psychometric assessments using the framework of the Consensus Statement. The number of patients enrolled and the number who completed the study at the last follow-up were abstracted. Age, prior stroke, and operative procedure were recorded. Because there is an impact of learning on repeat neuropsychological test administration, we recorded if learning was accounted for in the identification of POCD. In addition to these core features, we recorded if studies included assessment of anxiety and depression, because these conditions can impact cognitive testing. The Consensus Statement named four neuropsychological tests as a core battery to cover three cognitive domains (Figure 1) including the Rey Auditory Verbal Learning Test(11) for verbal memory, Trailmaking test $\mathrm{A}$ and $\mathrm{B}^{10}$ for attention, and grooved pegboard 11 for motor skills. For each study, we identified the number of the core tests utilized to assess POCD, the cognitive domains covered by the tests administered, and the postoperative timing of the follow-up assessments. $12 \mathrm{We}$ recorded the analytic criteria for POCD used and the prevalence of POCD reported.

\section{Results}

Figure 2 summarizes the search strategy and results. Abstracts identified with electronic databases $(n=1311)$ were reviewed for potential fit of the selection criteria and 190 articles were identified for full review. The full review included a manual search of references, which identified an additional 31 articles. Post-hoc inclusion of keywords from referencelist identified articles did not identify additional articles. Studies were also eliminated that were secondary analyses $(n=54)$, sample size $<50(n=40)$, used screening cognitive instruments only $(n=29)$, review articles $(n=16)$, and otherwise excluded (case reports, letters, dissertations $n=20$ ). Overall, sixty-two studies of postoperative cognitive dysfunction after cardiac surgery met inclusion criteria.

Studies are presented according to study design: Table 1 includes prospective cohort studies without controls $(n=14)$; Table 2 includes prospective studies with controls $(n=8)$; and Table 3 includes intervention studies $(n=40)$ of which 38 were randomized.

Table 4 describes the data collection by type of study. While most studies included some of the neuropsychological tests named in the Consensus Statement, less than half included all four tests. Coverage of the memory $(n=57 ; 95 \%)$ and attention $(n=56 ; 93 \%)$ domains was very good; while motor skill $(\mathrm{n}=36$; $60 \%)$ was less commonly measured. In prospective cohort studies with and without controls, postoperative testing was likely to occur after the recommended three month time period. However, slightly less than half of randomized controlled trials measured POCD after 3 months. Roughly half of studies reported preoperative assessments for depression and anxiety. The impact of learning was accounted 
for in very few studies and neurological exam was documented in less than half. One prospective study with controls ${ }^{13}, 14$ and one intervention study 15,16 adhered to the neuropsychological testing battery, test timing, and comorbidity measurement of the Consensus statement.

Table 5 lists the analytic criteria used to define POCD and the number of studies in which these criteria appear. Many studies analyzed POCD using more than one analysis methodology. There are four major analytic criteria for used for defining POCD. In the 'percentage decline' definition, a patient must decline a percentage (usually 20\%) from baseline in a specified number of tests (usually 2). The 'SD decline' criterion requires a reference population (baseline performance, normative data, or control) to define the standard deviation for the employed battery and then creates the dichotomous outcome based on a decline greater than the standard deviation. The reference population used to define the standard deviation is not consistent among studies, nor is the magnitude of the standard deviation decline (i.e. $1 \mathrm{SD}, 1.5 \mathrm{SD}, 2 \mathrm{SD}$ ). The 'factor analysis' methodology uses raw neuropsychological data to group highly correlated tests into several (3-4) latent cognitive domains, which are continuous variables. The latent cognitive domains can be dichotomized (usually at $1 \mathrm{SD}$ ) to define decline. 'Individual test analysis' assesses performance on individual neuropsychological measures and several continuous outcome variables. Individual test analysis generally does not create a dichotomous definition of decline. Finally, a growing number of studies $(n=10)$ are reporting continuous measures (Zscore) of neuropsychological performance, both as individual tests and as a composite. The composite score is generally a sum or mean of individual test Z-score change from baseline.

Table 6 reports the range of the prevalence of POCD by criteria and follow-up interval. There is a high degree of variability of the reported prevalence. In some cases, the ratio in prevalence from minimum to maximum is greater than ten-fold. Studies often showed an increase in POCD prevalence at longer follow-up intervals, but most of these studies did not account for the impact of age and atherosclerosis on cognitive function over these time periods.

\section{Discussion}

This review identified 62 studies that assessed POCD after cardiac surgery and examined the adherence to the recommendations of the Consensus Statement that was published in 1995. ${ }^{7}$ We found significant variability in the neuropsychological tests and the timing of the tests used to measure POCD. Most batteries covered the domains of attention and verbal memory, while motor function was measured less frequently. Half of studies assessed anxiety or depression and a few accounted for the learning effect. Consequently, standard analytic criteria for POCD did not emerge, indicating that the Consensus Statement guidelines are not widely accepted or applied. The resultant heterogeneity in how POCD is measured and defined may limit the ability to compare POCD outcomes across studies and possibly impede progress in the field.

Studies of cardiac surgery have inherent variability because of patient factors (age, education, comorbidity), cardiac surgery factors (hypothermia, cardiopulmonary bypass, cross clamp, bleeding), physiologic factors (inflammation, microembolization, blood brain barrier function), intraoperative factors (anesthesia, cerebral oxygenation, hypotension), perioperative factors (medication, sleep, complications), and postoperative factors (rehabilitation, depression, social supports). Identifying POCD in patients becomes more difficult when variable measurement of cognitive function with different neuropsychological tests and multiple analytic criteria are utilized. Thus, confronted with two POCD studies with different results, it is difficult to know whether the differences are substantive or simply 
related to how POCD is measured and defined. Development of standardized criteria for neuropsychiatric conditions such as delirium ${ }^{17}$, Alzheimer's disease18, and depression19 has allowed clinical and basic science research in these conditions to progress.

Ultimately, using standardized criteria creates a dichotomous definition of POCD. In this review, we found that recent studies analyze and report both a dichotomous definition and a continuous/summary measure of cognitive function. While calculation of a dichotomous definition has clinical applicability, it reduces statistical power in the study. Additionally, the mechanism of how multiple neuropsychological tests are combined into a single measure of cognitive function remains the subject of a debate because of the cognitive domain overlap of neuropsychological tests, the method of combination (e.g. mean/sum of Z-scores, confirmatory factor analysis, etc), and the impact of learning. Thus, it may be timely to utilize the wealth of evidence from recent studies to revisit measurement methods and definitions for POCD.

Importantly, the data from the studies identified in this review can play a key role in the development of a standardized battery and analytic criteria for POCD, which can address the challenges associated with POCD in several ways. First, each neuropsychological test measures more than one cognitive domain (e.g. Performance on Trailmaking requires attention as well as working memory and motor skills) and thus, the tests are highly correlated. As a result, impairment in one cognitive domain may have effects on tests that predominantly measure other cognitive domains (e.g. Impaired psychomotor skill will affect performance on Trailmaking, independent of attention or working memory). Using previous studies, a standardized cognitive battery would define the degree of contribution of a neuropsychological test to each cognitive domain and ensure adequate coverage of all appropriate cognitive domains. Second, the information about floor effects (i.e. poor initial performance which cannot decline) ${ }^{20}$ and ceiling effects (i.e. excellent initial performance which cannot improve) can be obtained from the current literature and used to optimize selection of neuropsychological tests to detect clinically significant change.21 Third, learning effects can be measured and factored into a standardized neuropsychological battery and analytic criteria for POCD. 15,22,23 The learning effect occurs because repeated administration of tests increases the knowledge of the test structure and thus, performance tends to improve with repeated administration. Fourth, a standardized battery would help define the test-retest reliability of the neuropsychological tests. Reliable neuropsychological tests are important to reduce regression to the mean, where performance at the extreme (high or low) will tend to move toward the mean on repeat testing.24 Finally, using the current literature, the contribution of individual variability vs. true change would likely be better characterized.20,21 For example, neuropsychological performance can be affected by factors not related to cognitive function (i.e. sleep the night prior, frustration of commute to testing center, or fatigue towards the end of testing). The current literature could be used to establish normative values for defining significant change. Ultimately, this change definition would need to be validated against a change in social or occupational function to demonstrate that it was clinically significant.

The development and validation of a standardized neuropsychological battery and analytic criteria could help advance POCD to the level of a clinical disorder by improving efficiency of measurement, identifying patients at high risk, and ensuring clinical meaning of the outcome. If POCD were more easily operationalized, smaller physician groups would be empowered to measure POCD to improve operative technique, anesthesia protocols, and perioperative care without requiring external funding to conduct a research study (reimbursement for cognitive testing may be necessary). A standardized battery and criteria would also be a boon to research in this area. For example, when standardized criteria for 
delirium were developed ${ }^{17}$ the number of research studies published on delirium increased by over $100 \%$ in the subsequent 10 years compared to the 10 years prior.

In conclusion, using the recommendations of the 1995 Statement of Consensus on Assessment of Neurobehavioral Outcomes after Cardiac Surgery as a framework, the present systematic literature review identified 62 unique studies of POCD and analyzed the adherence to these recommendations. While the cognitive domains of attention and memory are included in nearly all studies, there is significant variability in the coverage of other cognitive domains and in the individual neuropsychological tests used to measure POCD. Moreover, no standard analytic criteria for POCD have emerged. This heterogeneity limits the ability to compare POCD amongst studies. A unified battery and analytic criteria would improve comparability, address measurement challenges such as learning, floor, and ceiling effects, and ultimately, advance science in this field by allowing clinicians and investigators to develop a better understanding of the causes of POCD and thereby to develop strategies for its prevention or treatment.

\section{Acknowledgments}

Financial Disclosure: Dr Rudolph is supported by a VA Rehabilitation Research and Development Career Development Award. Additional support for this award was provided by NIH grants (AG026781, AG029861, AG027549, AG030618, AG028189, AG008812)

\section{References}

1. Likosky DS, Nugent WC, Ross CS. Improving outcomes of cardiac surgery through cooperative efforts: the northern new England experience. Semin Cardiothorac Vasc Anesth 2005;9:119-121. [PubMed: 15920635]

2. Jensen BO, Hughes P, Rasmussen LS, Pedersen PU, Steinbruchel DA. Health-related quality of life following off-pump versus on-pump coronary artery bypass grafting in elderly moderate to highrisk patients: a randomized trial. Eur J Cardiothorac Surg 2006;30:294-299. [PubMed: 16829089]

3. Rumsfeld JS, Magid DJ, O'Brien M, McCarthy M Jr, MaWhinney S Scd, Shroyer AL, Moritz TE, Henderson WG, Sethi GK, Grover FL, Hammermeister KE. Changes in health-related quality of life following coronary artery bypass graft surgery. Ann Thorac Surg 2001;72:2026-2032. [PubMed: 11789788]

4. Stump DA. Selection and clinical significance of neuropsychologic tests. Ann Thorac Surg 1995;59:1340-1344. [PubMed: 7733765]

5. Mahanna EP, Blumenthal JA, White WD, Croughwell ND, Clancy CP, Smith LR, Newman MF. Defining neuropsychological dysfunction after coronary artery bypass grafting. Ann Thorac Surg 1996;61:1342-1347. [PubMed: 8633938]

6. Blumenthal JA, Mahanna EP, Madden DJ, White WD, Croughwell ND, Newman MF. Methodological issues in the assessment of neuropsychologic function after cardiac surgery. Ann Thorac Surg 1995;59:1345-1350. [PubMed: 7733766]

7. Murkin JM, Newman SP, Stump DA, Blumenthal JA. Statement of consensus on assessment of neurobehavioral outcomes after cardiac surgery. Ann Thorac Surg 1995;59:1289-1295. [PubMed: 7733754]

8. Folstein MF, Folstein SE, McHugh PR. "Mini-mental state". A practical method for grading the cognitive state of patients for the clinician. J Psychiatr Res 1975;12:189-198. [PubMed: 1202204]

9. Rudolph JL, Marcantonio ER, Culley DJ, Silverstein JH, Rasmussen LS, Crosby GJ, Inouye SK. Delirium is associated with early postoperative cognitive dysfunction. Anaesthesia 2008;63:941947. [PubMed: 18547292]

10. Army Individual Test Battery, Manual of Direction and Scoring. Washington, DC: War Department Adjutant General's Office; 1944. Trailmaking Tests A and B.

11. Knights RM. Normative data on the motor steadiness battery for children. Percept Mot Skills 1968;26:643-650. [PubMed: 5659094] 
12. Newman S, Stygall J, Hirani S, Shaefi S, Maze M. Postoperative cognitive dysfunction after noncardiac surgery: a systematic review. Anesthesiology 2007;106:572-590. [PubMed: 17325517]

13. Selnes OA, Grega MA, Bailey MM, Pham L, Zeger S, Baumgartner WA, McKhann GM. Neurocognitive Outcomes 3 Years After Coronary Artery Bypass Graft Surgery: A Controlled Study. The Annals of Thoracic Surgery 2007;84:1885-1896. [PubMed: 18036903]

14. McKhann GM, Grega MA, Borowicz LM Jr, Bailey MM, Barry SJE, Zeger SL, Baumgartner WA, Selnes OA. Is there cognitive decline 1 year after CABG?: Comparison with surgical and nonsurgical controls. Neurology 2005;65:991-999. [PubMed: 16107605]

15. van Dijk D, Jansen EW, Hijman R, Nierich AP, Diephuis JC, Moons KG, Lahpor JR, Borst C, Keizer AM, Nathoe HM, Grobbee DE, De Jaegere PP, Kalkman CJ. Cognitive outcome after offpump and on-pump coronary artery bypass graft surgery: a randomized trial. JAMA 2002;287:1405-1412. [PubMed: 11903027]

16. van Dijk D, Spoor M, Hijman R, Nathoe HM, Borst C, Jansen EW, Grobbee DE, de Jaegere PP, Kalkman CJ. Cognitive and cardiac outcomes 5 years after off-pump vs on-pump coronary artery bypass graft surgery. JAMA 2007;297:701-708. [PubMed: 17312289]

17. Inouye SK, van Dyck CH, Alessi CA, Balkin S, Siegal AP, Horwitz RI. Clarifying confusion: the confusion assessment method. A new method for detection of delirium. Ann Intern Med 1990;113:941-948. [PubMed: 2240918]

18. McKhann G, Drachman D, Folstein M, Katzman R, Price D, Stadlan EM. Clinical diagnosis of Alzheimer's disease: report of the NINCDS-ADRDA Work Group under the auspices of Department of Health and Human Services Task Force on Alzheimer's Disease. Neurology 1984;34:939-944. [PubMed: 6610841]

19. Washington, DC: American Psychiatric Association; 2000. Diagnostic and statistical manual of mental disorders, fourth edition, text revision.

20. Slade P, Sanchez P, Townes B, Aldea GS. The use of neurocognitive tests in evaluating the outcome of cardiac surgery: some methodologic considerations. J Cardiothorac Vasc Anesth 2001;15:4-8. [PubMed: 11254831]

21. Cella D, Bullinger M, Scott C, Barofsky I. Group vs individual approaches to understanding the clinical significance of differences or changes in quality of life. Mayo Clin Proc 2002;77:384-392. [PubMed: 11936936]

22. Newman MF, Kirchner JL, Phillips-Bute B, Gaver V, Grocott H, Jones RH, Mark DB, Reves JG, Blumenthal JA. Longitudinal assessment of neurocognitive function after coronary-artery bypass surgery. N Engl J Med 2001;344:395-402. [PubMed: 11172175]

23. Selnes OA, Grega MA, Bailey MM, Pham LD, Zeger SL, Baumgartner WA, McKhann GM. Cognition 6 years after surgical or medical therapy for coronary artery disease. Ann Neurol 2008;63:581-590. [PubMed: 18481292]

24. Collie A, Darby DG, Falleti MG, Silbert BS, Maruff P. Determining the extent of cognitive change after coronary surgery: a review of statistical procedures. Ann Thorac Surg 2002;73:2005-2011. [PubMed: 12078822]

25. Walzer T, Herrmann M, Wallesch CW. Neuropsychological disorders after coronary bypass surgery. J Neurol Neurosurg Psychiatry 1997;62:644-648. [PubMed: 9219757]

26. Toner I, Taylor KM, Newman S, Smith PL. Cerebral functional changes following cardiac surgery: Neuropsychological and EEG assessment. Eur J Cardiothorac Surg 1998;13:13-20. [PubMed: 9504725]

27. Robson MJ, Alston RP, Deary IJ, Andrews PJ, Souter MJ, Yates S. Cognition after coronary artery surgery is not related to postoperative jugular bulb oxyhemoglobin desaturation. Anesth Analg 2000;91:1317-1326. [PubMed: 11093972]

28. Borger MA, Peniston CM, Weisel RD, Vasiliou M, Green REA, Feindel CM. Neuropsychologic impairment after coronary bypass surgery: Effect of gaseous microemboli during perfusionist interventions. Journal of Thoracic and Cardiovascular Surgery 2001;121:743-749. [PubMed: 11279417]

29. Di Carlo A, Perna AM, Pantoni L, Basile AM, Bonacchi M, Pracucci G, Trefoloni G, Bracco L, Sangiovanni V, Piccini C, Palmarini MF, Carbonetto F, Biondi E, Sani G, Inzitari D. Clinically 
relevant cognitive impairment after cardiac surgery: a 6-month follow-up study. J Neurol Sci 2001;188:85-93. [PubMed: 11489290]

30. Millar K, Asbury AJ, Murray GD. Pre-existing cognitive impairment as a factor influencing outcome after cardiac surgery. Br J Anaesth 2001;86:63-67. [PubMed: 11575412]

31. Newman MF, Kirchner JL, Phillips-Bute B, Gaver V, Grocott H, Jones RH, Mark DB, Reves JG, Blumenthal JA. The Neurological Outcome Research Group and the Cardiothoracic Anesthesiology Research Endeavors I. Longitudinal Assessment of Neurocognitive Function after Coronary-Artery Bypass Surgery. N Engl J Med 2001;344:395-402. [PubMed: 11172175]

32. Mullges W, Babin-Ebell J, Reents W, Toyka KV. Cognitive performance after coronary artery bypass grafting: a follow-up study. Neurology 2002;59:741-743. [PubMed: 12221167]

33. Ho PM, Arciniegas DB, Grigsby J, McCarthy M Jr, McDonald GO, Moritz TE, Shroyer AL, Sethi GK, Henderson WG, London MJ, VillaNueva CB, Grover FL, Hammermeister KE. Predictors of cognitive decline following coronary artery bypass graft surgery. Ann Thorac Surg 2004;77:597603. discussion 03. [PubMed: 14759444]

34. Askar FZ, Cetin HY, Kumral E, Cetin O, Acarer A, Kosova B, Yagdi T. Apolipoprotein E4 Allele and Neurobehavioral Status After On-Pump Coronary Artery Bypass Grafting. Journal of Cardiac Surgery 2005;20:501-505. [PubMed: 16153291]

35. Dupuis G, Kennedy E, Lindquist R, Barton FB, Terrin ML, Hoogwerf BJ, Czajkowski SM, Herd JA. Coronary artery bypass graft surgery and cognitive performance. Am J Crit Care 2006;15:471-478. quiz 79. [PubMed: 16926368]

36. Kadoi Y, Goto F. Factors Associated with Postoperative Cognitive Dysfunction in Patients Undergoing Cardiac Surgery. Surgery Today 2006;36:1053-1057. [PubMed: 17123132]

37. Puskas F, Grocott HP, White WD, Mathew JP, Newman MF, Bar-Yosef S. Intraoperative hyperglycemia and cognitive decline after CABG. Ann Thorac Surg 2007;84:1467-1473. [PubMed: 17954047]

38. Tagarakis G, Tsolaki-Tagaraki F, Tsolaki M, Diegeler A, Kazis D, Rouska E, Papassotiropoulos A. The role of SOAT-1 polymorphisms in cognitive decline and delirium after bypass heart surgery. Clinical Research in Cardiology 2007;96:600-603. [PubMed: 17593314]

39. Vingerhoets G, Van Nooten G, Vermassen F, De Soete G, Jannes C. Short-term and long-term neuropsychological consequences of cardiac surgery with extracorporeal circulation. Eur J Cardiothorac Surg 1997;11:424-431. [PubMed: 9105803]

40. Andrew MJ, Baker RA, Bennetts J, Kneebone AC, Knight JL. A comparison of neuropsychologic deficits after extracardiac and intracardiac surgery. Journal of Cardiothoracic and Vascular Anesthesia 2001;15:9-14. [PubMed: 11254832]

41. Fearn SJ, Pole R, Wesnes K, Faragher EB, Hooper TL, McCollum CN. Cerebral injury during cardiopulmonary bypass: emboli impair memory. J Thorac Cardiovasc Surg 2001;121:1150-1160. [PubMed: 11385383]

42. Zimpfer D, Czerny M, Vogt F, Schuch P, Kramer L, Wolner E, Grimm M. Neurocognitive deficit following coronary artery bypass grafting: a prospective study of surgical patients and nonsurgical controls. Ann Thorac Surg 2004;78:513-518. discussion 18-9. [PubMed: 15276509]

43. Kneebone AC, Luszcz MA, Baker RA, Knight JL. A syndromal analysis of neuropsychological outcome following coronary artery bypass graft surgery. J Neurol Neurosurg Psychiatry 2005;76:1121-1127. [PubMed: 16024891]

44. Raymond PD, Hinton-Bayre AD, Radel M, Ray MJ, Marsh NA. Assessment of statistical change criteria used to define significant change in neuropsychological test performance following cardiac surgery. European Journal of Cardio-Thoracic Surgery 2006;29:82-88. [PubMed: 16337395]

45. Sweet JJ, Finnin E, Wolfe PL, Beaumont JL, Hahn E, Marymont J, Sanborn T, Rosengart TK. Absence of cognitive decline one year after coronary bypass surgery: comparison to nonsurgical and healthy controls. Ann Thorac Surg 2008;85:1571-1578. [PubMed: 18442540]

46. Baba T, Goto T, Maekawa K, Ito A, Yoshitake A, Koshiji T. Early neuropsychological dysfunction in elderly high-risk patients after on-pump and off-pump coronary bypass surgery. Journal of Anesthesia 2007;21:452-458. [PubMed: 18008111]

47. Liu YH, Wang DX, Li LH, Wu XM, Shan GJ, Su Y, Li J, Yu QJ, Shi CX, Huang YN, Sun W. The effects of cardiopulmonary bypass on the number of cerebral microemboli and the incidence of 
cognitive dysfunction after coronary artery bypass graft surgery. Anesth Analg 2009;109:10131022. [PubMed: 19762724]

48. Gold JP, Charlson ME, Williams-Russo P, Szatrowski TP, Peterson JC, Pirraglia PA, Hartman GS, Yao FS, Hollenberg JP, Barbut D, et al. Improvement of outcomes after coronary artery bypass. A randomized trial comparing intraoperative high versus low mean arterial pressure. J Thorac Cardiovasc Surg 1995;110:1302-1311. discussion 11-4. [PubMed: 7475182]

49. Murkin JM, Martzke JS, Buchan AM, Bentley C, Wong CJ. A randomized study of the influence of perfusion technique and $\mathrm{pH}$ management strategy in 316 patients undergoing coronary artery bypass surgery. I. Mortality and cardiovascular morbidity. J Thorac Cardiovasc Surg 1995;110:340-348. [PubMed: 7637351]

50. Mora CT, Henson MB, Weintraub WS, Murkin JM, Martin TD, Craver JM, Gott JP, Guyton RA. The effect of temperature management during cardiopulmonary bypass on neurologic and neuropsychologic outcomes in patients undergoing coronary revascularization. J Thorac Cardiovasc Surg 1996;112:514-522. [PubMed: 8751521]

51. Patel RL, Turtle MR, Chambers DJ, James DN, Newman S, Venn GE. Alpha-stat acid-base regulation during cardiopulmonary bypass improves neuropsychologic outcome in patients undergoing coronary artery bypass grafting. J Thorac Cardiovasc Surg 1996;111:1267-1279. [PubMed: 8642829]

52. Regragui I, Birdi I, Izzat MB, Black AM, Lopatatzidis A, Day CJ, Gardner F, Bryan AJ, Angelini GD. The effects of cardiopulmonary bypass temperature on neuropsychologic outcome after coronary artery operations: a prospective randomized trial. J Thorac Cardiovasc Surg 1996;112:1036-1045. [PubMed: 8873731]

53. Arrowsmith JE, Harrison MJ, Newman SP, Stygall J, Timberlake N, Pugsley WB. Neuroprotection of the brain during cardiopulmonary bypass: a randomized trial of remacemide during coronary artery bypass in 171 patients. Stroke 1998;29:2357-2362. [PubMed: 9804648]

54. Stygall J, Newman SP, Fitzgerald G, Steed L, Mulligan K, Arrowsmith JE, Pugsley W, Humphries $\mathrm{S}$, Harrison MJ. Cognitive change 5 years after coronary artery bypass surgery. Health Psychol 2003;22:579-586. [PubMed: 14640854]

55. Browne SM, Halligan PW, Wade DT, Taggart DP. Cognitive performance after cardiac operation: implications of regression toward the mean. J Thorac Cardiovasc Surg 1999;117:481-485. [PubMed: 10047650]

56. Taggart DP, Browne SM, Wade DT, Halligan PW. Neuroprotection during cardiac surgery: a randomised trial of a platelet activating factor antagonist. Heart 2003;89:897-900. [PubMed: 12860868]

57. Lloyd CT, Ascione R, Underwood MJ, Gardner F, Black A, Angelini GD. Serum S-100 protein release and neuropsychologic outcome during coronary revascularization on the beating heart: a prospective randomized study. J Thorac Cardiovasc Surg 2000;119:148-154. [PubMed: 10612774]

58. Grigore AM, Grocott HP, Mathew JP, Phillips-Bute B, Stanley TO, Butler A, Landolfo KP, Reves JG, Blumenthal JA, Newman MF. The Rewarming Rate and Increased Peak Temperature Alter Neurocognitive Outcome After Cardiac Surgery. Anesth Analg 2002;94:4-10. [PubMed: 11772792]

59. Grigore AM, Mathew J, Grocott HP, Reves JG, Blumenthal JA, White WD, Smith PK, Jones RH, Kirchner JL, Mark DB, Newman MF. Prospective randomized trial of normothermic versus hypothermic cardiopulmonary bypass on cognitive function after coronary artery bypass graft surgery. Anesthesiology 2001;95:1110-1119. [PubMed: 11684979]

60. Nathan HJ, Wells GA, Munson JL, Wozny D. Neuroprotective effect of mild hypothermia in patients undergoing coronary artery surgery with cardiopulmonary bypass: a randomized trial. Circulation 2001;104:I85-I91. [PubMed: 11568036]

61. Nathan HJ, Rodriguez R, Wozny D, Dupuis JY, Rubens FD, Bryson GL, Wells G. Neuroprotective effect of mild hypothermia in patients undergoing coronary artery surgery with cardiopulmonary bypass: five-year follow-up of a randomized trial. J Thorac Cardiovasc Surg 2007;133:1206-1211. [PubMed: 17467430] 
62. Heyer EJ, Lee KS, Manspeizer HE, Mongero L, Spanier TB, Caliste X, Esrig B, Smith C. Heparinbonded cardiopulmonary bypass circuits reduce cognitive dysfunction. Journal of Cardiothoracic and Vascular Anesthesia 2002;16:37-42. [PubMed: 11854876]

63. Kong RS, Butterworth J, Aveling W, Stump DA, Harrison MJ, Hammon J, Stygall J, Rorie KD, Newman SP. Clinical trial of the neuroprotectant clomethiazole in coronary artery bypass graft surgery: a randomized controlled trial. Anesthesiology 2002;97:585-591. [PubMed: 12218524]

64. Wang D, Wu X, Li J, Xiao F, Liu X, Meng M. The Effect of Lidocaine on Early Postoperative Cognitive Dysfunction After Coronary Artery Bypass Surgery. Anesth Analg 2002;95:1134-1141. [PubMed: 12401580]

65. Zamvar VY, Khan NU, Madhavan A, Kulatilake N, Butchart EG. Clinical outcomes in coronary artery bypass graft surgery: comparison of off-pump and on-pump techniques. Heart Surg Forum 2002;5:109-113. [PubMed: 12114123]

66. Lee JD, Lee SJ, Tsushima WT, Yamauchi H, Lau WT, Popper J, Stein A, Johnson D, Lee D, Petrovitch H, Dang CR. Benefits of off-pump bypass on neurologic and clinical morbidity: a prospective randomized trial. Ann Thorac Surg 2003;76:18-25. discussion 25-6. [PubMed: 12842506]

67. Mathew JP, Shernan SK, White WD, Fitch JC, Chen JC, Bell L, Newman MF. Preliminary report of the effects of complement suppression with pexelizumab on neurocognitive decline after coronary artery bypass graft surgery. Stroke 2004;35:2335-2339. [PubMed: 15331798]

68. Wahrborg P, Booth JE, Clayton T, Nugara F, Pepper J, Weintraub WS, Sigwart U, Stables RH. Neuropsychological outcome after percutaneous coronary intervention or coronary artery bypass grafting: results from the Stent or Surgery (SoS) Trial. Circulation 2004;110:3411-3417. [PubMed: 15557380]

69. Whitaker DC, Newman SP, Stygall J, Hope-Wynne C, Harrison MJ, Walesby RK. The effect of leucocyte-depleting arterial line filters on cerebral microemboli and neuropsychological outcome following coronary artery bypass surgery. Eur J Cardiothorac Surg 2004;25:267-274. [PubMed: 14747125]

70. Butterworth J, Wagenknecht LE, Legault C, Zaccaro DJ, Kon ND, Hammon JW Jr, Rogers AT, Troost BT, Stump DA, Furberg CD, Coker LH. Attempted control of hyperglycemia during cardiopulmonary bypass fails to improve neurologic or neurobehavioral outcomes in patients without diabetes mellitus undergoing coronary artery bypass grafting. J Thorac Cardiovasc Surg 2005;130:1319. [PubMed: 16256784]

71. Lund C, Sundet K, Tennøe B, Hol PK, Rein KA, Fosse E, Russell D. Cerebral Ischemic Injury and Cognitive Impairment After Off-Pump and On-Pump Coronary Artery Bypass Grafting Surgery. The Annals of Thoracic Surgery 2005;80:2126-2131. [PubMed: 16305857]

72. Al-Ruzzeh S, George S, Bustami M, Wray J, Ilsley C, Athanasiou T, Amrani M. Effect of offpump coronary artery bypass surgery on clinical, angiographic, neurocognitive, and quality of life outcomes: randomised controlled trial. Bmj 2006;332:1365. [PubMed: 16740529]

73. Ernest CS, Worcester MUC, Tatoulis J, Elliott PC, Murphy BM, Higgins RO, Le Grande MR, Goble AJ. Neurocognitive Outcomes in Off-Pump Versus On-Pump Bypass Surgery: A Randomized Controlled Trial. The Annals of Thoracic Surgery 2006;81:2105-2114. [PubMed: 16731138]

74. Hammon JW, Stump DA, Butterworth JF, Moody DM, Rorie K, Deal DD, Kincaid EH, Oaks TE, Kon ND. Single crossclamp improves 6-month cognitive outcome in high-risk coronary bypass patients: The effect of reduced aortic manipulation. The Journal of Thoracic and Cardiovascular Surgery 2006;131:114-121. [PubMed: 16399302]

75. Jensen BO, Hughes P, Rasmussen LS, Pedersen PU, Steinbruchel DA. Cognitive outcomes in elderly high-risk patients after off-pump versus conventional coronary artery bypass grafting: a randomized trial. Circulation 2006;113:2790-2795. [PubMed: 16769915]

76. Jensen BO, Rasmussen LS, Steinbruchel DA. Cognitive outcomes in elderly high-risk patients 1 year after off-pump versus on-pump coronary artery bypass grafting. A randomized trial. Eur J Cardiothorac Surg 2008;34:1016-1021. [PubMed: 18778948]

77. Silbert BS, Scott DA, Evered LA, Lewis MS, Kalpokas M, Maruff P, Myles PS, Jamrozik K. A comparison of the effect of high- and low-dose fentanyl on the incidence of postoperative 
cognitive dysfunction after coronary artery bypass surgery in the elderly. Anesthesiology 2006;104:1137-1145. [PubMed: 16732083]

78. Szalma I, Kiss Á, Kardos L, Horváth G, Nyitrai E, Tordai Z, Csiba L. Piracetam Prevents Cognitive Decline in Coronary Artery Bypass: A Randomized Trial Versus Placebo. The Annals of Thoracic Surgery 2006;82:1430-1435. [PubMed: 16996947]

79. Boodhwani M, Rubens F, Wozny D, Rodriguez R, Nathan HJ. Effects of sustained mild hypothermia on neurocognitive function after coronary artery bypass surgery: a randomized, double-blind study. J Thorac Cardiovasc Surg 2007;134:1443-1450. discussion 51-2. [PubMed: 18023662]

80. Hogue CW Jr, Freedland K, Hershey T, Fucetola R, Nassief A, Barzilai B, Thomas B, Birge S, Dixon D, Schechtman KB, Davila-Roman VG. Neurocognitive outcomes are not improved by 17beta-estradiol in postmenopausal women undergoing cardiac surgery. Stroke 2007;38:20482054. [PubMed: 17510454]

81. Djaiani G, Fedorko L, Borger MA, Green R, Carroll J, Marcon M, Karski J. Continuous-Flow Cell Saver Reduces Cognitive Decline in Elderly Patients After Coronary Bypass Surgery. Circulation 2007;116:1888-1895. [PubMed: 17923575]

82. Hernandez F Jr, Brown JR, Likosky DS, Clough RA, Hess AL, Roth RM, Ross CS, Whited CM, O'Connor GT, Klemperer JD. Neurocognitive Outcomes of Off-Pump Versus On-Pump Coronary Artery Bypass: A Prospective Randomized Controlled Trial. The Annals of Thoracic Surgery 2007;84:1897-1903. [PubMed: 18036904]

83. Tully PJ, Baker RA, Kneebone AC, Knight JL. Neuropsychologic and quality-of-life outcomes after coronary artery bypass surgery with and without cardiopulmonary bypass: a prospective randomized trial. J Cardiothorac Vasc Anesth 2008;22:515-521. [PubMed: 18662624]

84. Slater JP, Guarino T, Stack J, Vinod K, Bustami RT, Brown JM 3rd, Rodriguez AL, Magovern CJ, Zaubler T, Freundlich K, Parr GV. Cerebral oxygen desaturation predicts cognitive decline and longer hospital stay after cardiac surgery. Ann Thorac Surg 2009;87:36-44. discussion 44-5. [PubMed: 19101265]

85. Mathew JP, Mackensen GB, Phillips-Bute B, Grocott HP, Glower DD, Laskowitz DT, Blumenthal JA, Newman MF. Randomized, double-blinded, placebo controlled study of neuroprotection with lidocaine in cardiac surgery. Stroke 2009;40:880-887. [PubMed: 19164788]

86. Mitchell SJ, Merry AF, Frampton C, Davies E, Grieve D, Mills BP, Webster CS, Milsom FP, Willcox TW, Gorman DF. Cerebral protection by lidocaine during cardiac operations: a follow-up study. Ann Thorac Surg 2009;87:820-825. [PubMed: 19231397]

87. Stygall J, Suvarna S, Harrington J, Hayward M, Walesby RK, Newman SP. Effect on the brain of two techniques of myocardial protection. Asian Cardiovasc Thorac Ann 2009;17:259-265. [PubMed: 19643849]

88. Hudetz JA, Iqbal Z, Gandhi SD, Patterson KM, Byrne AJ, Hudetz AG, Pagel PS, Warltier DC. Ketamine attenuates post-operative cognitive dysfunction after cardiac surgery. Acta Anaesthesiol Scand 2009;53:864-872. [PubMed: 19422355]

89. Shroyer AL, Grover FL, Hattler B, Collins JF, McDonald GO, Kozora E, Lucke JC, Baltz JH, Novitzky D. On-pump versus off-pump coronary-artery bypass surgery. N Engl J Med 2009;361:1827-1837. [PubMed: 19890125] 


\section{Consensus Criteria}

Neurologic exam before and after surgery

Cognitive assessment prior to surgery

When possible, control or comparison group

Recommended Cognitive Test Battery

Trailmaking A

Trailmaking B

Rey auditory verbal learning test

Grooved pegboard

Tests should be free of sex, race, and ethnic bias

No single test will identify postoperative cognitive dysfunction

Tests performed in standardized environmental conditions

Tests performed by same person before and after surgery

Mood state assessments (depression and anxiety) performed concurrently

At least one assessment $\geq 3$ months after surgery

Account for the learning effect

Figure 1.

Elements of the Statement of Consensus on Assessment of Neurobehavioral Outcomes After Cardiac Surgery (adapted from 7) 


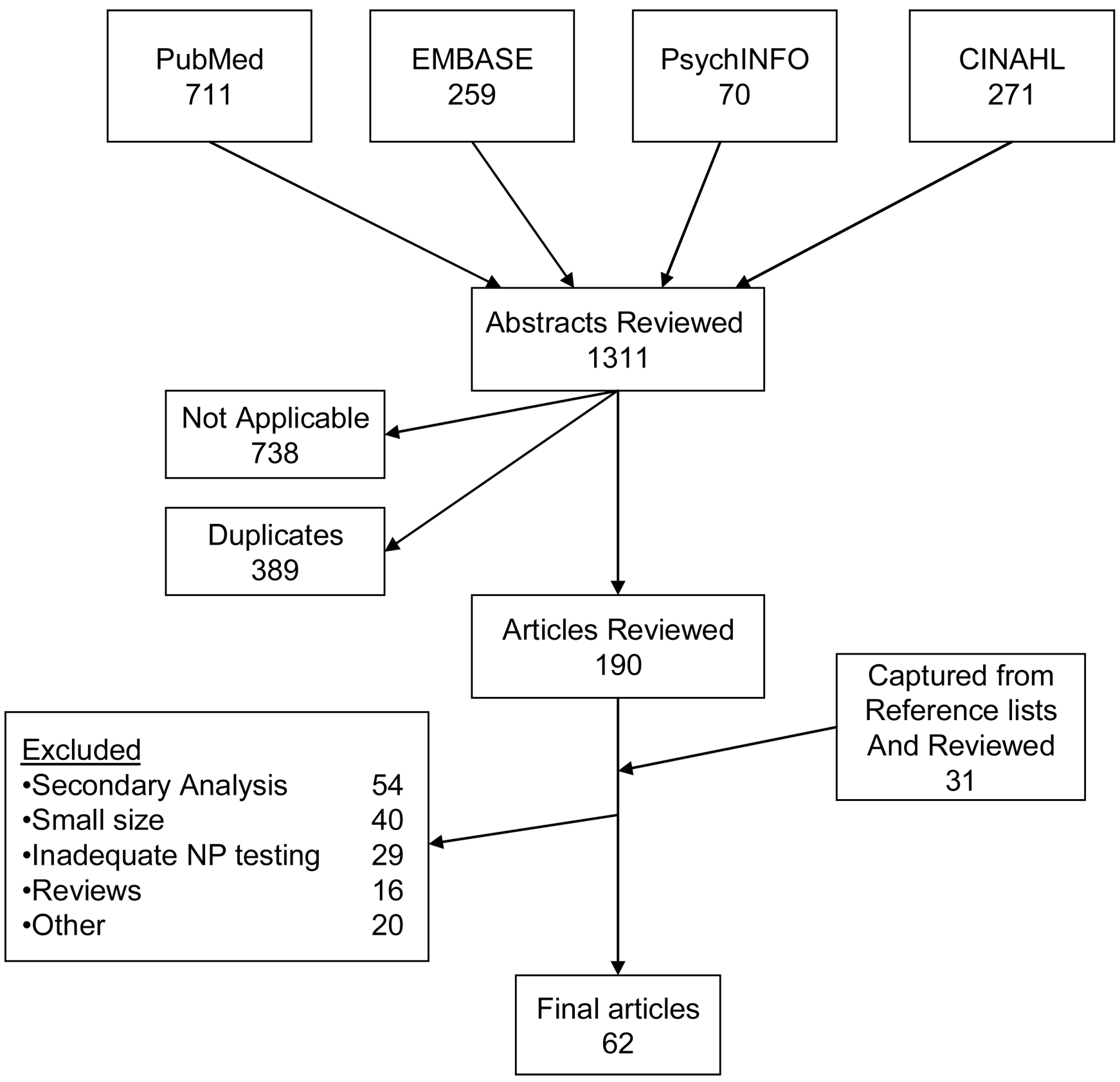

Figure 2.

Flow Diagram of Article Selection Process

CINAHL - cumulative index to nursing and allied health literature; NP- neuropsychological; 


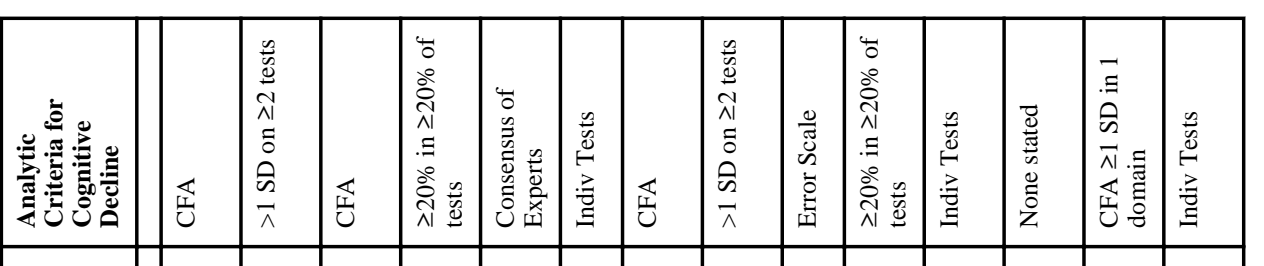

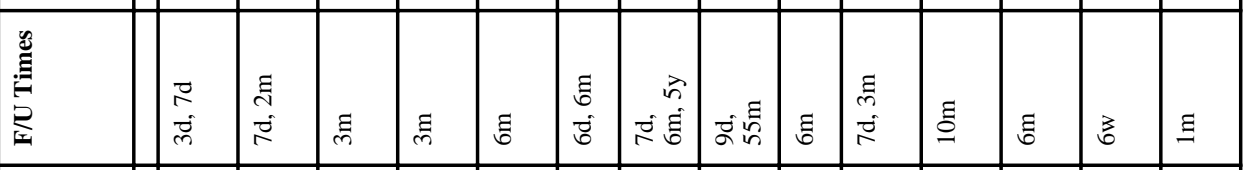

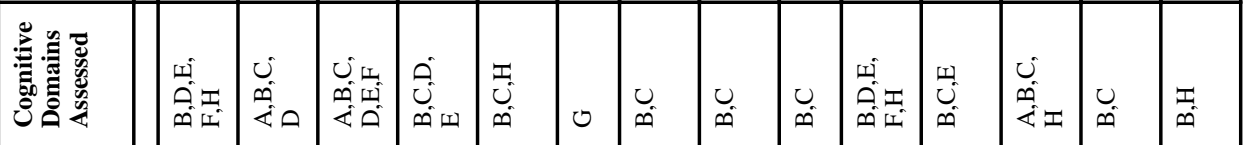

\begin{tabular}{|l|l|l|l|l|l|l|l|l|l|l|l|l|l|}
\hline 5 & & & & & \\
\hline 5
\end{tabular}

要竞
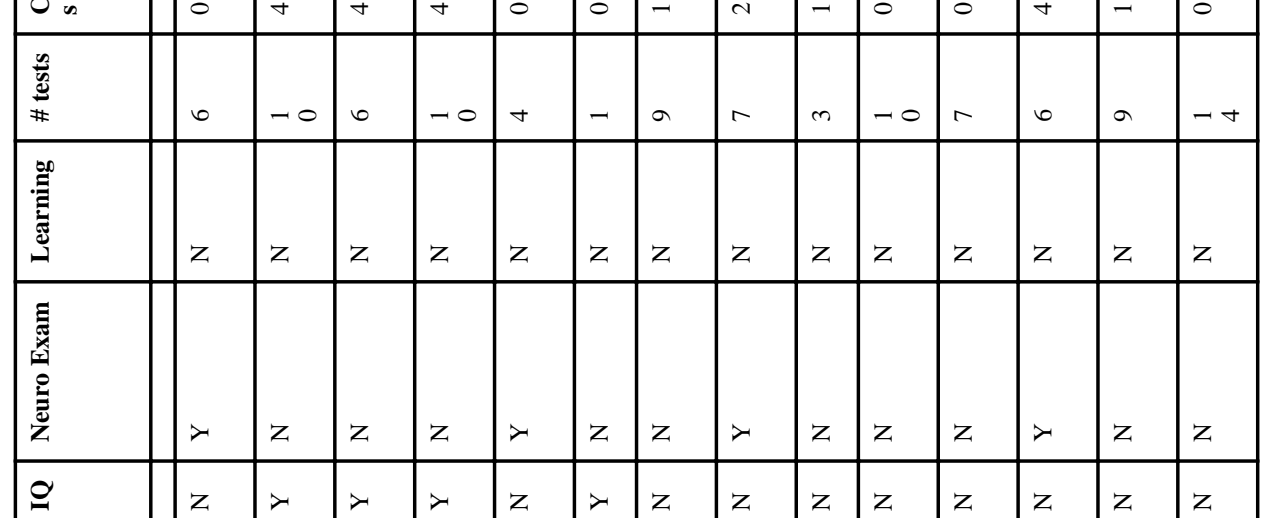

\begin{tabular}{|l|l|l|l|l|l|l|l|l|l|}
\hline & $x$ & $z$ & $z$ & $z$ & $z$ & $z$ & $z$ & $z$ & $z$ \\
\hline
\end{tabular}

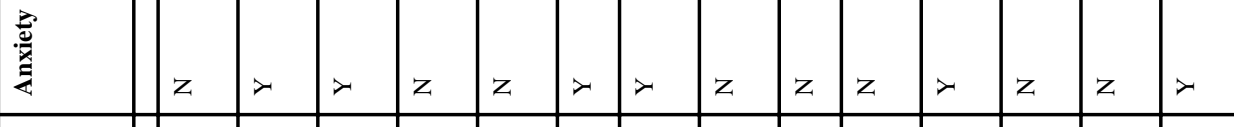

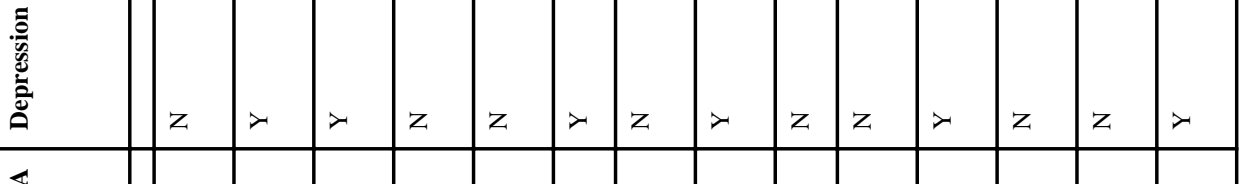

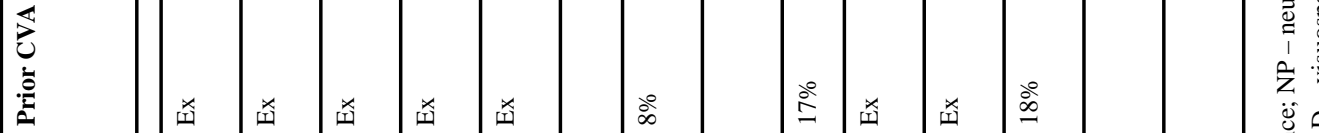

\begin{tabular}{|c|c|c|c|c|c|c|c|c|c|c|c|c|c|c|}
\hline 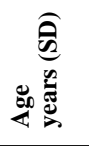 & $\bar{\sigma}$ & 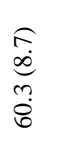 & ڤે & 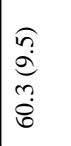 & 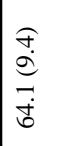 & $\begin{array}{l}\widehat{\vec{\theta}} \\
\overline{\vec{\theta}}\end{array}$ & 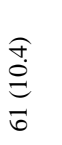 & 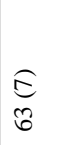 & 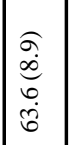 & 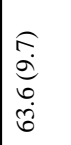 & 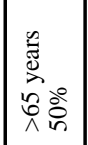 & 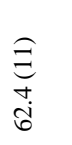 & 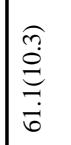 & 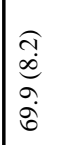 \\
\hline 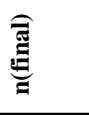 & $尺$ & న్ర & $\stackrel{\Xi}{\varrho}$ & $\infty$ & $\cong$ & $\vec{\infty}$ & $\underline{\Xi}$ & $i$ & के & $\cong$ & ஃ̊ & $\infty$ & $\tilde{n}$ & $\hat{\mathfrak{g}}$ \\
\hline 吾 & $\stackrel{\infty}{\infty}$ & તુ & $\stackrel{\varrho}{\leftrightarrows}$ & $\infty$ & $\cong$ & $\bar{\infty}$ & $\overrightarrow{\mathrm{i}}$ & $\bar{\sigma}$ & $\underline{\underline{6}}$ & 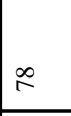 & : & $\approx$ & $\stackrel{2}{2}$ & 志 \\
\hline 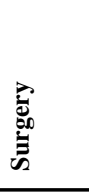 & 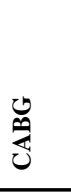 & 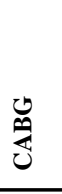 & 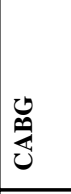 & 造 & 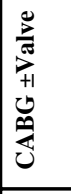 & 递 & U. & 递 & $\begin{array}{l}0 \\
\tilde{3} \\
\tilde{3}\end{array}$ & 递 & 递 & 参 & 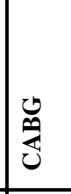 & 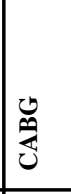 \\
\hline 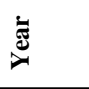 & बू & $\stackrel{\infty}{\stackrel{\infty}{2}}$ & \&్రి & $\overrightarrow{\mathrm{O}}$ & $\overrightarrow{\mathrm{o}}$ & $\overline{\mathrm{d}}$ & ఫ్ & ర్రి & 䓂 & 产 & 迅 & : & 总 & పे \\
\hline 总 & 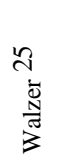 & 总 & 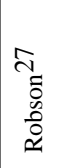 & 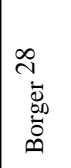 & 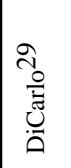 & 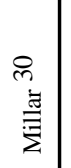 & 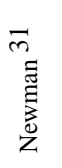 & 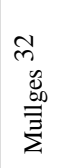 & 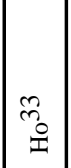 & 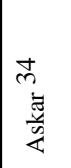 & $\mid \begin{array}{l}n_{2} \\
\vdots \\
\vdots \overline{\bar{z}} \\
n\end{array}$ & 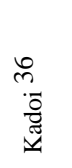 & 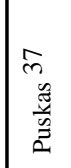 & 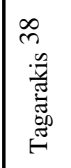 \\
\hline
\end{tabular}

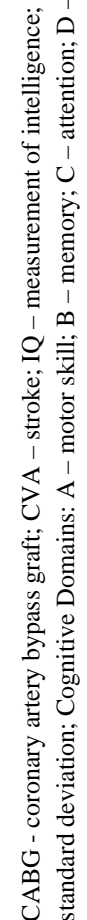




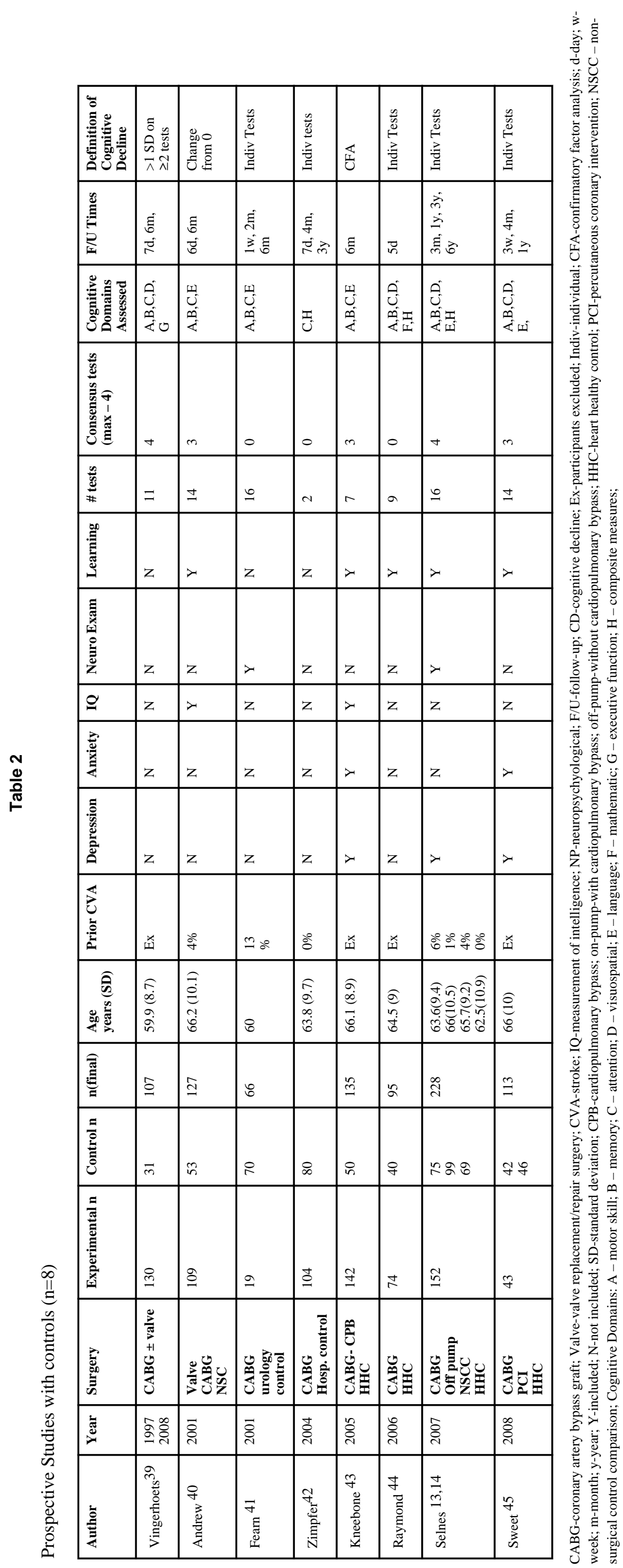

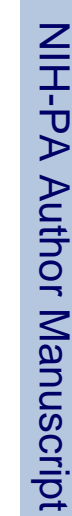

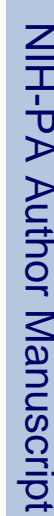

Acta Anaesthesiol Scand. Author manuscript; available in PMC 2011 July 1. 


\begin{tabular}{|c|c|c|c|c|c|c|c|c|c|c|c|c|c|}
\hline 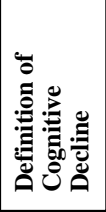 & 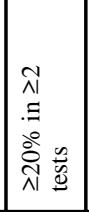 & 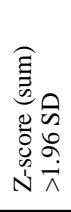 & 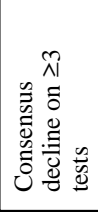 & 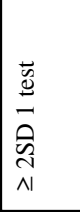 & 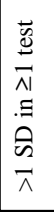 & 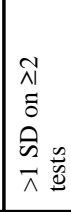 & 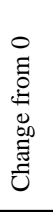 & 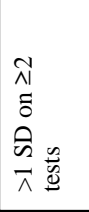 & 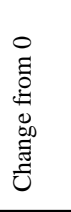 & 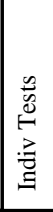 & 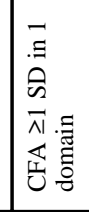 & 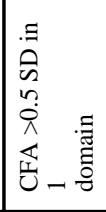 & 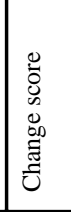 \\
\hline 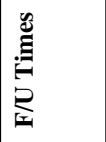 & $\because$ & 跑 & $\Xi$ & 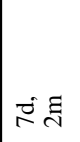 & $\Xi$ & $\exists$ & z & 离离 & $\underline{z} \bar{m}$ & I & $\xi$ & 涪 & 㶽 \\
\hline
\end{tabular}

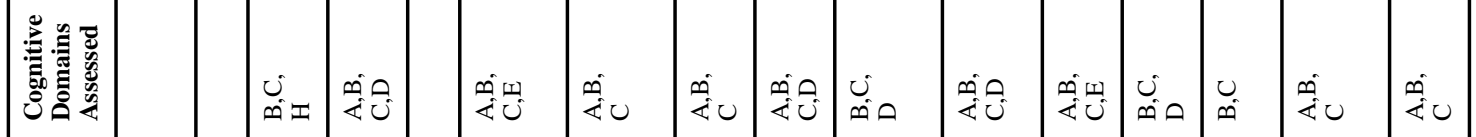

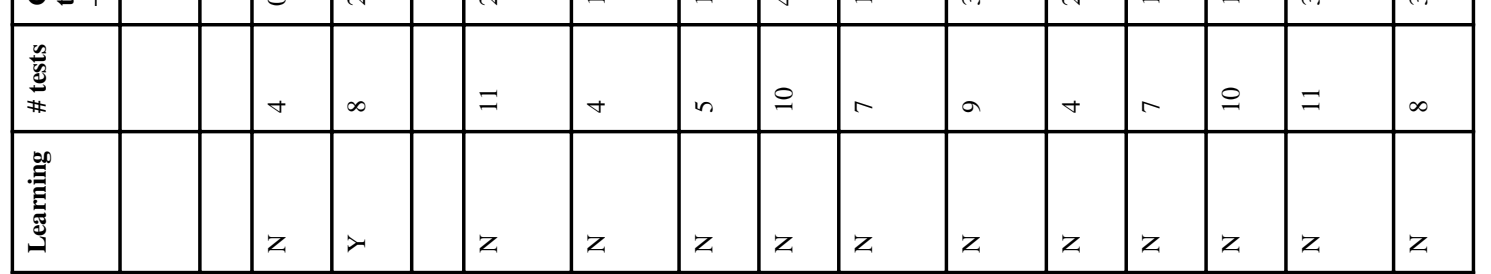

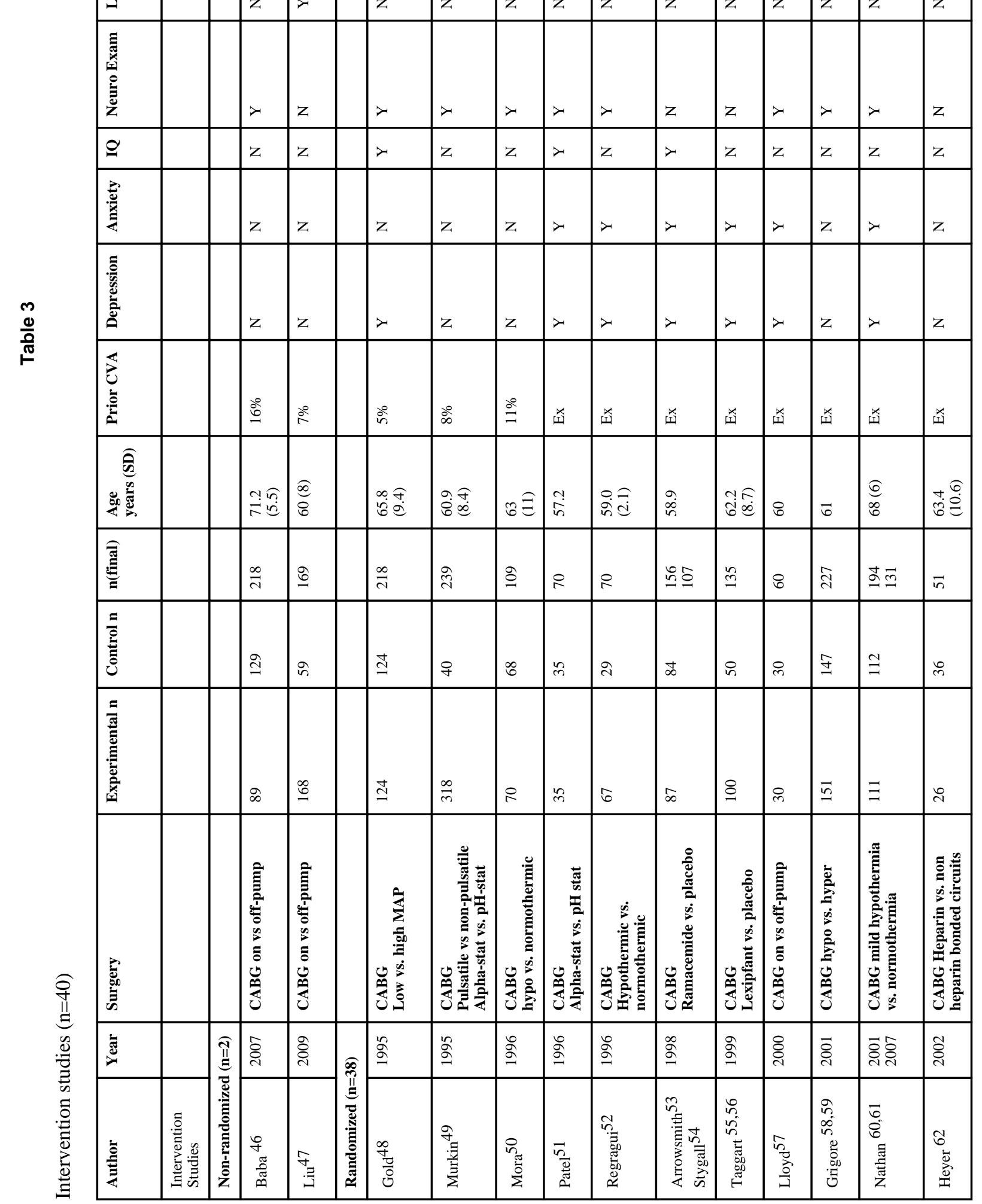




\begin{tabular}{|c|c|c|c|c|c|c|c|c|c|c|c|c|c|c|c|}
\hline 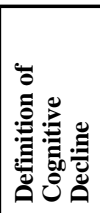 & 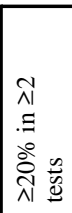 & 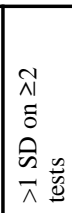 & 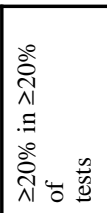 & 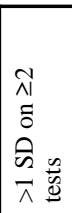 & 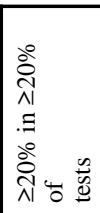 & 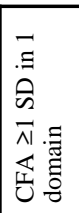 & 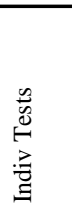 & 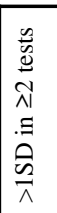 & 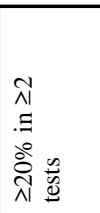 & 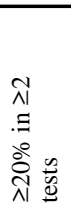 & 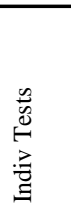 & 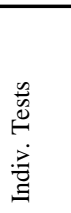 & 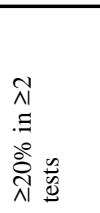 & 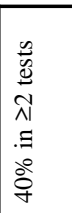 & 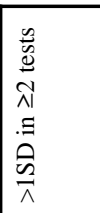 \\
\hline 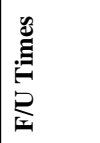 & B & zू & $\dot{m} \vec{m}$ & iْo & $\vec{N} \gtrsim$ & $\dot{子} \Xi$ & हुㅁㅇ & 3 & 戈主 & 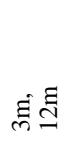 & है & 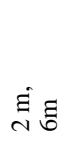 & 字主节 & $\dot{\tilde{m}} \gtrsim$ & 立之 \\
\hline
\end{tabular}

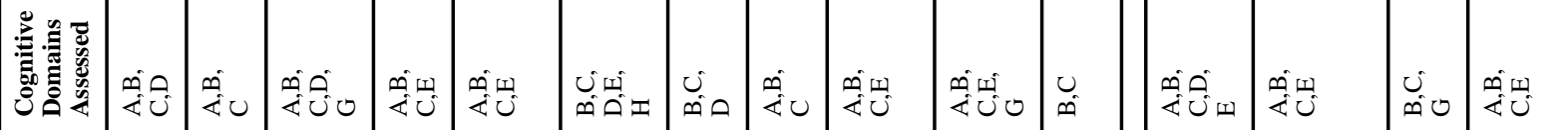

竞

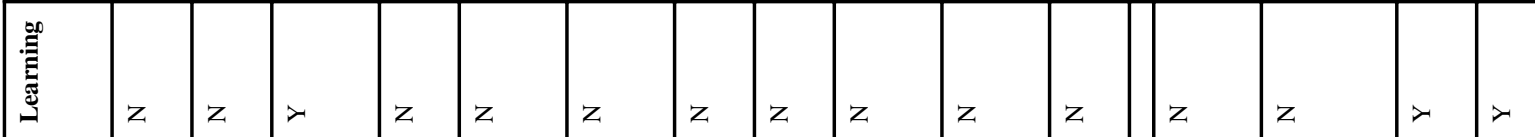

\begin{tabular}{|c|c|c|c|c|c|c|c|c|c|c|c|c|c|c|c|}
\hline 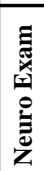 & $\lambda$ & $z$ & $\lambda$ & $z$ & $\lambda$ & $\lambda$ & $\lambda$ & $z$ & $\lambda$ & $\mathrm{z}$ & z & $z$ & $z$ & $z$ & $\mathrm{z}$ \\
\hline$\stackrel{\varrho}{0}$ & z & z & $z$ & $\lambda$ & $z$ & $z$ & $z$ & $z$ & z & $z$ & $z$ & $\lambda$ & z & $z$ & $\lambda$ \\
\hline
\end{tabular}

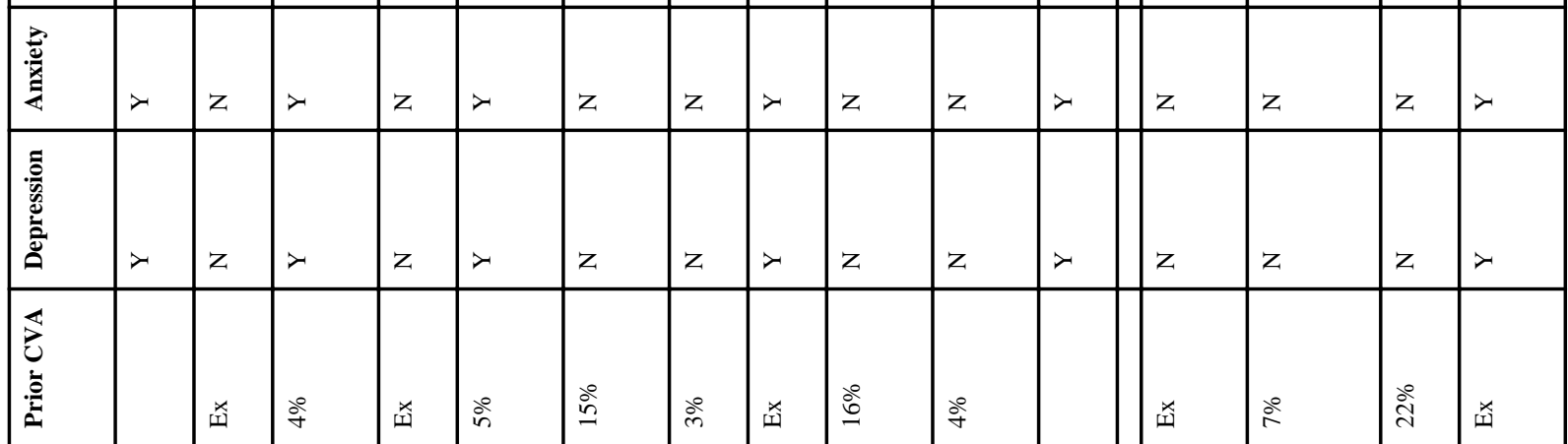

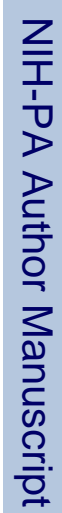

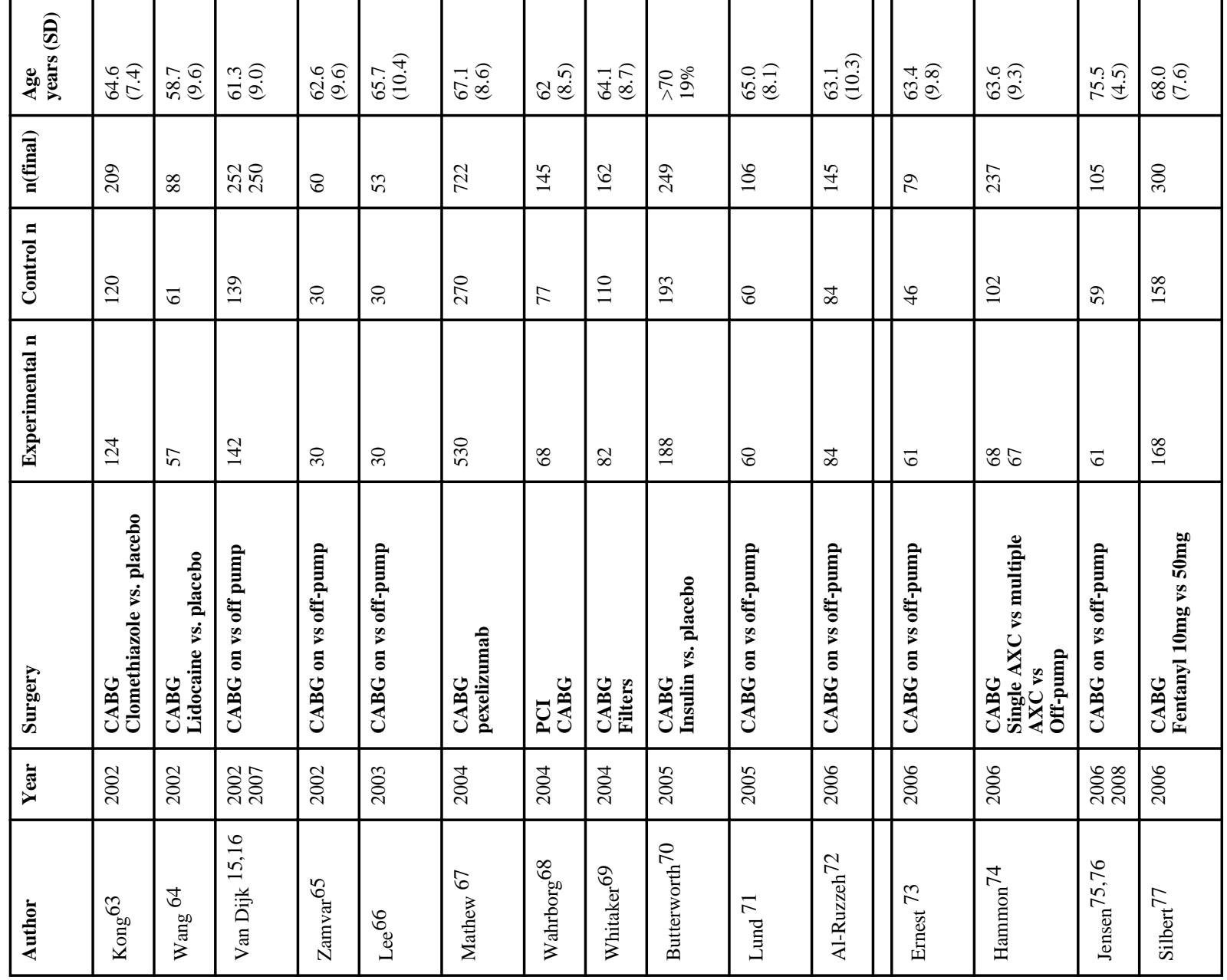




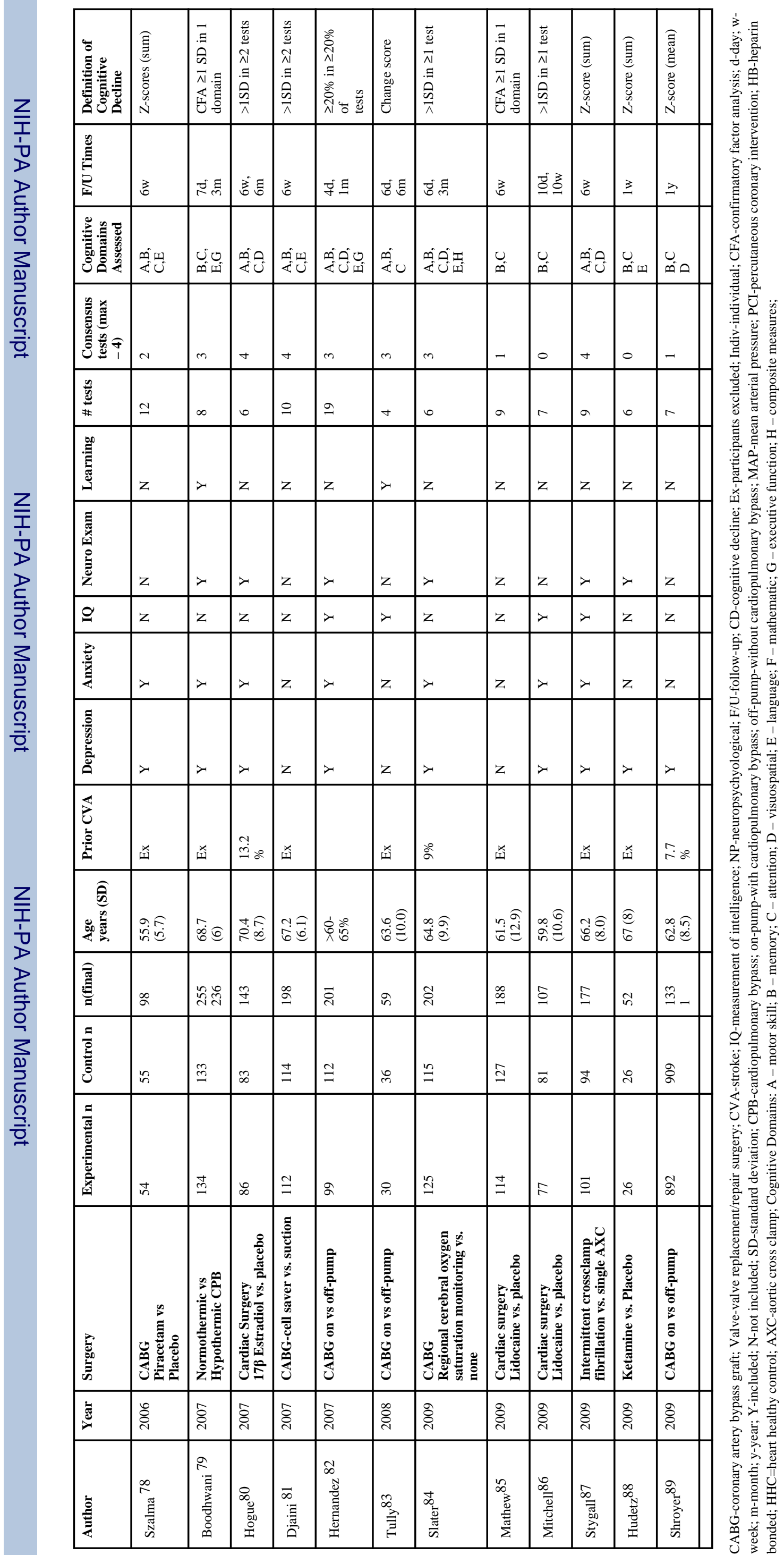


Table 4

Adherence to Consensus Statement Recommendations

\begin{tabular}{|c|c|c|c|}
\hline & $\begin{array}{c}\text { Prospective Cohort } \\
\text { without controls } \\
n=14\end{array}$ & $\begin{array}{c}\text { Prospective Cohort } \\
\text { without controls } \\
n=8\end{array}$ & 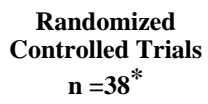 \\
\hline \multicolumn{4}{|l|}{ Recommended Consensus Battery } \\
\hline \multicolumn{4}{|l|}{ Tests } \\
\hline None & $6(43 \%)$ & $3(38 \%)$ & $6(16 \%)$ \\
\hline 1 & $3(21 \%)$ & $2(25 \%)$ & $6(16 \%)$ \\
\hline 2 & $1(7 \%)$ & $0(0 \%)$ & $5(13 \%)$ \\
\hline 3 & $0(0 \%)$ & $3(38 \%)$ & $8(21 \%)$ \\
\hline 4 & $4(29 \%)$ & $2(25 \%)$ & $13(34 \%)$ \\
\hline \multicolumn{4}{|l|}{ Recommended Cognitive } \\
\hline \multicolumn{4}{|l|}{ Domains Tested } \\
\hline Motor skill & $3(21 \%)$ & $7(88 \%)$ & $26(68 \%)$ \\
\hline Verbal memory & $12(86 \%)$ & $7(88 \%)$ & $38(100 \%)$ \\
\hline Attention and concentration & $10(71 \%)$ & $8(100 \%)$ & $38(100 \%)$ \\
\hline Postoperative testing $\geq 3$ months & $10(71 \%)$ & $7(88 \%)$ & $18(47 \%)$ \\
\hline Anxiety & $6(43 \%)$ & $2(25 \%)$ & $19(50 \%)$ \\
\hline Depression & $6(43 \%)$ & $3(38 \%)$ & $22(58 \%)$ \\
\hline IQ & $4(29 \%)$ & $2(25 \%)$ & $10(26 \%)$ \\
\hline Neurologic Exam & $4(29 \%)$ & $2(25 \%)$ & $20(53 \%)$ \\
\hline Learning / Practice Effects & $0(0 \%)$ & $5(63 \%)$ & $5(13 \%)$ \\
\hline
\end{tabular}

* Two non-randomized studies were not included in table totals 


\section{Table 5}

Analytic Criteria of Postoperative Cognitive Decline

\begin{tabular}{lc}
\hline Definition of Cognitive Decline & Number $^{*}$ \\
\hline Percent decline & 15 \\
$>1$ SD on 2 tests & 14 \\
Factor Analysis & 13 \\
Individual Test Analysis & 12 \\
Z-scores (sum/mean) & 10 \\
Change from 0 & 6 \\
Consensus of Experts & 2 \\
Other & 4 \\
Multiple Standardized Regression & 4 \\
\hline
\end{tabular}

* Numbers sum to more than the number of studies, because some studies examined more than one definition of decline 


\section{Table 6}

Median (range) of POCD prevalence according to the most common criteria* and time from surgery

\begin{tabular}{lccc}
\hline $\begin{array}{l}\text { Timing of } \\
\text { assessment }\end{array}$ & Factor Analysis & SD Decline & Percent Decline \\
\hline $1-21$ days & $48 \%(14-62 \%)$ & $46 \%(7-79 \%)$ & $51 \%(7-70 \%)$ \\
$22 \mathrm{~d}-5 \mathrm{~m}$ & $24 \%(4-46 \%)$ & $21 \%(0-49 \%)$ & $26 \%(6-51 \%)$ \\
$6 \mathrm{~m}-1 \mathrm{yr}$ & $24 \%(7-44 \%)$ & $15 \%(12-23 \%)$ & $24 \%(13-57 \%)$ \\
$>1 \mathrm{yr}$ & $42 \%(42-44 \%)$ & $\mathrm{n} / \mathrm{a}$ & $24 \%(23-50 \%)$ \\
\hline * &
\end{tabular}

